\title{
The Impact of the Employers' Brand on Personal Brand Orientation
}

\author{
Nguyen Thi Thuy \\ Lecturers \\ Faculty of Human Resource Management \\ University of Labor and Social Affairs (The Second Building) \\ Ho Chi Minh City, Viet Nam
}

\begin{abstract}
Today, employer branding is seen as a strategic solution to attract and retain talented people of businesses in a competitive human resource market. Since then, research has focused on presenting concepts related to personal brand orientation and employer branding. At the same time, mention some of the grounds that show an impact of employer brand on personal brand orientation. The results of this study will help researchers to continue to evaluate the relationship between employer brands and personal brand orientation by quantitative methods in many different research contexts.
\end{abstract}

Key Words: Employer Brand, Personal Brand, Personal Brand Orientation.

\section{INTRODUCTION}

In the trend of trade liberalization, maintaining competitive advantage and increasing economic profits is the goal that all economic organizations are pursuing. To achieve these goals, organizations must combine many different resources and motivate human resources is one of the keys, decisive factors for the success of the organization. The conclusion from the World Economic Forum, many business leaders are aware that: "human resources are the most valuable and important asset in the development of the organization". Therefore, attracting and retaining talents becomes the top concern in business management. Among the factors that make the business successful, people are always seen as the most important asset, and how to recruit talent and keep them in the company for a long time. Is a big challenge for business owners. Branding and human resources are confirmed as two core factors, two great challenges for the success of businesses in the 21 st century. Force to retain talented people of enterprises in the competitive human resource market.

Most of them, enterprises have to face challenges in competing in human resources with foreign enterprises, multinational corporations. The quality of trained human resources is not high, not meeting the needs of businesses. Enterprises must invest large amounts of money in recruitment to attract and recruit good people with appropriate skills and capacity to work. Moreover, many good and experienced employees tend to change jobs when they switch to work for a rival company or develop a separate business line. In addition to retaining existing employees, businesses have also begun to develop strategies to attract potential candidates.

\section{LITERATURE SURVEY}

\subsection{Individual Brand Orientation}

In marketing research, the concept of "brand orientation" is a concept that is rarely mentioned (Urde, 1999) and mainly in the field of organizational brand management. Brand orientation emphasizes the importance of brand identity (mission, vision, and value) as a "guidance" and cultural center of the organization, guiding the behavior and strategy of the team (Urde, 2013). Brand orientation is an internal, identity-oriented approach that considers brands as the center of an organization and its strategy is different from the "market-oriented" approach based on the external image. The concept of "brand orientation" is a new kind of 
orientation, a hybrid between branding and marketing orientation. This is a relatively new research concept (Urde, 2013) in marketing science. If a company is brand-oriented, it creates value and meaning through its brands.

A personal brand is the sum of all impressions, beliefs, and perceptions of an individual and a person (An Pham, 2018). In modern society, personal brand name (PB) is very important, if a person has a strong brand, their influence can greatly dominate the thoughts and actions of many others. Everyone has their brand (McNally, D. \& Speak, K.D., 2002) that sets them apart from others. A personal brand is a willingness to adhere to an agreed standard performance level (McNally \& Speak, 2002) and a strong personal brand is a blend of reputation, trust, attention, and expression. outside (execution) (Harris \& Rae, 2011). According to Montoya (2002), Montoya \& Vandehey (2008), a personal brand that encompasses professional and personal qualities, distinguishes one person from another, between their colleagues and their competitors, and implying or promising something of value (Arruda, 2004). A personal brand reflects the existence of a particular kind of personal understanding of the attitudes and feelings of others. McNally and Speak (2002) believe that a personal brand encompasses the internal and external characteristics of a person, that is, others' impressions of the person and of their interactions with that person. Based on this point of view, personal branding is not related to the creation of an image, but rather the combination of a person's unique expressions including personality, strengths (strengths, skills, values, passion, lifestyle, public image, and the individual identities to guide the decisions of the surname.

In a nutshell, "Personal brand orientation is an internal approach that aims to identify an individual's identity, manifest and build into a personal brand and see it as a strategy to compete. in the person's field of work".

\subsection{Employer Brands}

"Employer Brand" (Employer Brand) has been launched since the mid-1990s. Employer brand is understood as identity, is the prestige of the company brand as the only employer, instead of the name of a company in the market. An employer brand image is an image associated with a single organization as the employer rather than the type of company image that is approached to a broader audience like customers, suppliers... (Balmer, 1995, 2001 \& 2003).

The concept of the employer branding provides a strategic framework that combines both marketing and human resources (Moroko and Unère 2008; Ambler and Barrow 1996) so that an organization can attract and motivates existing employees who can add value to a company and can deliver a company's brand commitment (Moroko, 2005). Research by Knox \& Freeman (2006) and Lievens et al (2007) focuses on employer brand awareness, using a framework developed by Dutton \& Dukerich (1991).

According to Dukerich \& Carter (2000), employer brand including internal brand (internal) is often approached from the perception of employees within the enterprise, and brand is evaluated from the outside (external) including 2 One aspect is the employee's perception of outsiders, awareness of the company's brand and the other is the perception of potential candidates outside the enterprise of the corporate brand image as an employer (excerpt from Simon Knox \& Cheryl Freeman, 2006). In this study, the employer branding concept only deals with the internal brand aspect. Thus, "employer brand is the level of awareness of existing employees about the attractiveness of corporate identity and reputation as the only employer".

The benefits of a strong employer brand are obvious: helping companies gain a competitive advantage, helping employees absorb corporate values, reducing labor costs, improving industrial relations, employee retention, and even lower pay compared to companies with weak employer brands. Employer branding is now used in practice as a "long-term, targeted strategy to manage the perception and perception of employees, potential candidates, and other stakeholders related to a particular company".

Employer brands create two main types of assets: brand associations and brand loyalty. While brand loyalty contributes to increased employee productivity.

\subsection{The effect of the Employer brand on Personal brand}

The Social Identity Approach to Organizational Identity (SIA) provides a particularly useful approach for studying the attractiveness of an employer brand as organizational identity has been found to increase enhancing a range of behaviors that can support corporate branding; it motivates employees to engage in organizational civic behavior (Van Dick et al., 2005; Dukerich et al., 2002; Tyler \& Blader, 2000), to present an organization's positive image to all parties. Relevant (Dutton \& Dukerich 1991), thinking and acting in a unique way reflect the unique identity of the organization (Haslam et al., 2000; Dutton et al., 1994). When viewed through the lens of SIA, the recognized organization's brand image is the same in terms of the employer's brand image and the power of employees identifying their organization has been found to increase as they find themselves (identity) as attractive and unique (Dutton et al., 1994; Oakes \& Turner, 1986; Mael, 1988; Tajfel and Turner, 1979). The organizational identity can therefore be considered as the intervention variable between an organization's employer brand and the behavior of its employees. Furthermore, the SIA theory also provides evidence that an organization's brand as an employer if unique and engaging can motivate employees to engage in organizational civic behaviors and to live in business. brand (According to Rachael \& Knox, 2009). 
In other words, this theory shows that there is a certain interference between organizational brand management through promoting employer brand identity within the organization, promoting employees' implementation. Envisioned by the organization and the current employee's branding practices in the realization of the organization's overall goals. The candidates said that "personal branding" helps to build certain credibility and affirm its value in the market, thereby bringing trust to partners and bringing new business opportunities.

\section{CONCLUSION}

The employer brand is approached according to the internal branding aspect, which means assessing from the employees who are working for the enterprise the awareness of the attractiveness of the corporate brand as the employer. This is not only about the satisfaction with the organization, although many previous studies have proven it, the identity is also the reputation of the company as an employer. Accordingly, employees are aware of the value of the employer brand, if they perceive the compatibility and compatibility between their identity and the organizational identity, they will decide to work and stay for a long time. long with the organization as part of the organization. Besides, the decision to choose to work and stick with a reputable organization in the labor market contributes to increasing the value of individuals, helping them to "enhance" their owns name if like being recruited, being employed, collaborating, being employed by branded employers. Although there are no studies that directly assess the impact of employers' brands on personal brands, these are the bases to help further studies evaluate and prove this effect through research. quantitative research. From there, giving more specific implications to help businesses have a reasonable policy in retaining employees and increasing their motivation to work.

\section{REFERENCES}

[1] Ambler, T., \& Barrow, S. (1996). The employer brand. Journal of brand management, 4(3), 185-206.

[2] An, P. (2018), Định vị thương hiệu cá nhân. http://tapchitaichinh.vn/tai-chinh-kinh-doanh/xay-dung-thuong-hieu-ca-nhan-thoiky-cach-mang-cong-nghiep-40-309895.html

[3] Backhaus, K., and Tikoo, S. (2004). Conceptualizing and researching employer branding. Career Development International, $9(5), 501-517$.

[4] Balmer, j. M., van riel, c. B., hatch, m. J., \& schultz, m. (1997). Relations between organizational culture, identity and image. European journal of marketing.

[5] Balmer, j. M., harris, f., \& de chernatony, 1. (2001). Corporate branding and corporate brand performance. European journal of marketing.

[6] Harris, L., \& Rae, A. (2011). Building a personal brand through social networking. Journal of Business Strategy.

[7] Knox, S., \& Freeman, C. (2006). Measuring and managing employer brand image in the service industry. Journal of Marketing Management, 22(7-8), 695-716.

[8] Lievens, F., and Highhouse, S. (2003). The relation of instrumental and symbolic attributes to a company's atractiveness as an employer. Personnel Psychology, 56(1), 75-102.

[9] McNally, D., \& Speak, K. D. (2002). Be your own brand: A breakthrough formula for standing out from the crowd. San Francisco, CA: Berrett-Koehler.

[10] Montoya, C. M. (2008). Filipinos in Hollywood. Arcadia Publishing.

[11] Montoya, P., \& Vandehey, T. (2002). The personal branding phenomenon: realize greater influence, explosive income growth and rapid career advancement by applying the branding techniques of Michael, Martha \& Oprah. Peter Montoya.

[12] Moroko, L., \& Uncles, M. D. (2008). Characteristics of successful employer brands. Journal of brand management, 16(3), 160-175.

[13] Sullivan, J. (2004). The 8 Elements of a Successful Employment Brand. New York.

[14] Urde, M., Baumgarth, C., \& Merrilees, B. (2013). Brand orientation and market orientation-From alternatives to synergy. Journal of Business Research, 66(1), 13-20. 